\title{
ANALISIS SWOT TERHADAP STRATEGI PEMASARAN RUMAH MAKAN SAMBEL ALU
}

\author{
Khairunnisaa, Della Irachmi, Devi Lestari, Fauziah Rahayu, Vicky.F. Sanjaya \\ Universitas Islam Negeri Raden Intan Lampung \\ khairunnisaa000@gmail.com, dellairachmi98@gmail.com,devilestari030798@gmail.com, \\ fauziahrahayu09@gmail.com,vicky@ radenintan.ac.id
}

\begin{abstract}
ABSTRAK
Sambel Alu kini telah menjadi bisnis yang diminati oleh masyarakat Bandar lampung. Rumah Makan Sambel Alu menghadapi persaingan yang ketat dari pesaing kuliner lainnya. Penelitian ini bertujuan untuk menganalisis lingkungan internal dan eksternal Rumah Makan Sambel Alu dengan menggunakan analisis SWOT. Strategi yang didapatkan yaitu mempertahankan citra rumah makan, menjaga kualitas pelayanan konsumen, melakukan inovasi produk, menambah kerjasama dengan berbagai pihak, memperluas pengetahuan masyarakat, menggunakan teknologi terkini untuk pemasaran, meningkatkan keefektifan promosi, dan melakukan inovasi pemasaran pada rumah makan.
\end{abstract}

Kata kunci : Analisis SWOT, Pemasaran

\begin{abstract}
Sambel Alu has now become a business that is in demand by the Bandar Lampung community. This business grows rapidly. Sambel Alu Restaurant faces tight competition from competitors and other culinary. This research aims to analyze the internal and external environment of Sambal Alu Restaurant by using SWOT analysis. The strategies obtained are maintaining the image of the restaurant, maintaining the quality of consumer services, innovating products, increasing cooperation with various parties, expanding public knowledge, using the latest technology for marketing, increasing the effectiveness of promotions, and innovating marketing at home.
\end{abstract}

Keywords: SWOT analysis, Marketing 


\section{PENDAHULUAN}

Rumah makan adalah bisnis yang menyajikan makanan dan minuman serta menyediakan fasilitas tempat bagi konsumennya. Setiap menjalankan bisnis pastinya owner atau pemilik usaha tersebut memiliki strategi untuk menjadikan usahanya lebih berkembang. Seperti Rumah Makan Sambel Alu yang merupakan rumah makan yang sudah dikenal banyak orang di Bandar Lampung dimana memiliki menu yang berbeda dari rumah makan lainnya atau memiliki ciri khasnya tersendiri.

Setiap sektor bisnis pasti memiliki banyak pesaing sehingga pebisnis harus memiliki ciri khas tersendiri untuk membedakan bisnisnya dari pesaing. Perumusan strategi yang tepat bagi bisnis agar memiliki ciri khas salah satunya dengan melakukan analisis lingkungan perusahaan baik secara internal maupun eksternal dan alat atau model yang bisa dipakai adalah analisis SWOT (Strengths, Weaknesses, Opportunities and Threats Analysis).

Analisis SWOT merupakan analisis yang biasanya dilakukan dalam bisnis, dengan cara mencari tahu kekuatan dan peluang sebuah usaha serta cara meminimalkan ancaman dan kelemahan dari sebuah usaha tersebut, dan pada akhirnya dapat diputuskan stategi apa sesuai agar usaha tersebut dapat memiliki keunggulan bersaing dalam Industri.

Analisis SWOT terbagi dalam dua bagian, yaitu analisis internal yang terdiri dari kekuatan dan kelemahan, dan analisis eksternal yang terdiri dari peluang dan ancaman, yang mana pada analisis eksternal perusahaan tidak mempunyai kemampuan untuk mengendalikannya.

Berdasarkan kondisi latar belakang yang telah diuraikan, maka peneliti ingin menganalisis lebih dalam bagaimana keadaan lingkungan internal dan eksternal Rumah makan Sambel Alu Bandar Lampung sehingga dapat merumuskan strategi yang dapat di terapkan bagi konsumen pada Rumah Makan Sambal Alu. Berdasarkan penjelasan sebelumnya di Rumah Makan Sambel Alu, maka tujuan dalam penelitian ini yaitu :

1) Kekuatan apa yang dimiliki oleh Rumah Makan Sambel Alu

2) Kelemahan apa yang dimiliki oleh Rumah Makan Makan Sambel Alu

3) Peluang apa yang dimiliki oleh Rumah Makan Makan Sambel Alu dalam melakukan pemasaran

4) Ancaman apa yang dihadapi oleh Rumah Makan Sambel Alu dalam memasarkan produknya

\section{KAJIAN LITERATUR \\ Definisi Pemasaran}

Strategi menurut Chandler (1962) adalah sebagai tujuan dalam jangka waktu yang panjang dari suatu perusahaan, serta pendayagunaan dan alokasi semua sumber daya yang penting untuk mencapai tujuan tersebut (Fredy Rangkuti, 2005:3). Serdamayanti (2014:2) menyatakan bahwa strategi adalah rencana jangka panjang, yang berdampingan dengan tindakan serta ditujukan untuk mencapai suatu tujuan, yang memiliki arti "kemenangan".

John A. Bryne menjelaskan strategi sebagai dasar dari suatu pola untuk mencapai sasaran yang direncanakan, penyebaran sumber daya dan hubungan timbal balik organisasi dengan pasar, pesaing dan faktor-faktor lingkungan, sedangkan Jack Trout membicarakan strategi adalah bagaimana caranya bertahan hidup dalam dunia yang kompetitif, bagaimana membuat persepsi berbeda dalam benak konsumen, mencari tau kekuatan dan kelemahan pesaing, menjadi spesialisasi, kepemimpinan yang memberi arah dan memahami keadaan 
pasar dengan menjadi yang pertama dan lebih baik dibandingkan dengan yang lainnya (Suyanto,2007:16).

Strategi secara umum dapat diartikan sebagai alat untuk mencapai suatu tujuan, sedangkan menurut Kolter (1999) strategi pemasaran adalah suatu logika pemasaran yang dilaksanakan pada tiap bagian dengan harapan mencapai tujuan yang baik dan dapat mencapai sasaran pemasaran. Strategi pemasaran itu sendiri terdiri dari strategi spesifik bagi pasar sasaran, penentuan posisi produk, bauran pemasaran serta tingkat pengeluaran pemasaran. Pemasaran itu sendiri dapat diartikan dengan sebuah konsep ilmu dalam strategi bisnis yang bertujuan untuk mencapai suatu kepuasan berkelanjutan bagi stakeholder (konsumen, karyawan, dan pemilik saham).

Pemasaran kalau dipandang sebagai disiplin ilmu merupakan ilmu pengetahuan yang objektif yang dapat diperoleh dengan penggunaan instrument-instrumen tertentu untuk mengukur suatu kinerja dari aktivitas bisnis dalam membentuk, mengembangkan, mengarahkan pertukaran yang saling menguntungkan antara produsen dan konsumen. Pemasaran jika dipandang sebagai strategi bisnis merupakan tindakan penyesuaian suatu organisasi yang menganalisis pasar baik dalam lingkungan mikro maupun lingkungan makro yang tidak stabil.

Menurut Irawan (1998:10), pemasaran merupakan suatu proses sosial yang mana individu dan kelompok mendapatkan yang dibutuhkan dan yang diinginkan dengan menciptakan produk dan nilai dengan individu atau kelompok lainnya. Hasan (2013:1) menyatakan pemasaran didefinisikan sebagai proses mengidentifikasi, menemukan, mengomunikasikan nilai, dan menjaga hubungan yang tujuannya untuk memuaskan pelanggan demi memaksimalkan sebuah keuntungan perusahaan

Menurut Kotler dan Amstrong (2008:7), pemasaran merupakan suatu proses yang mana perusahaan menciptakan nilai guna untuk konsumen dan membangun suatu hubungan yang kuat dengan konsumen yang bertujuan untuk menciptakan nilai keuntungan dari konsumen. American Marketing Association (AMA) mendefinisikan pemasaran sebagai suatu fungsi dari sebuah organisasi dan serangkaian proses untuk menemukan, mengomunikasikan, dan memberikan nilai kepada pelanggan dan mengelola hubungan pelanggan yang menguntungkan organisasi serta pemangku kepentingannya. (Kotler dan Keller; 2009:5). Pemasaran selalu dikaitkan dengan aktivitas bisnis yang melayani konsumen.

Menurut Kotler (2003), pemasaran dapat didefinisikan dengan suatu proses sosial yang akan membuat individu dan kelompok memperoleh apa yang mereka butuhkan serta inginkan. Pemasaran merupakan keseluruhan dari kegiatan usaha yang tujuannya untuk merencanakan menciptakan harga, mempromosikan dan mengenalkan barang dan jasa yang dapat memuaskan kebutuhan konsumen maupun pembeli yang potensial. (Winarni, Wisnubroto dan Suyatno, 2010). Jadi, pemasaran tidak akan selalu melibatkan pertukaran secara ekonomi antara dua pihak tetapi lebih luas lagi yaitu dapat berupa pertukaran sosial.

\section{Strategi Pemasaran}

Menurut Marrus dalam Umar (2001:31) strategi dapat di jelaskan sebagai suatu proses penentuan rencana untuk para pemimpin puncak yang berfokus hanya pada tujuan jangka panjang organisasi, serta penyusunan upaya bagaimana agar tujuan tersebut dapat dicapai. Strategi dapat diartikan secara khusus sebagai tindakan yang bersifat incremental atau senantiasa meningkat dan terus-menerus, lalu dilakukan berdasarkan sudut pandang 
yang dibutuhkan oleh konsumen di masa datang nantinya (Prahalad dalam Umar, 2001:31).

Menurut Chandra (2002:93), strategi pemasaran merupakan rencana yang menjelaskan secara detail suatu harapan atau rencana perusahaan dampak dari berbagai macam aktivitas atau program pemasaran terhadap permintaan produk di pasar sasaran tertentu. Program pemasaran yaitu suatu tindakan-tindakan pemasaran yang memengaruhi permintaan terhadap produk, diantaranya dengan mengubah harga, memodifikasi proses iklan, membuat promosi khusus dan juga menentukan pilihan saluran distribusi.

\section{Perumusan Strategi Pemasaran:}

\section{Strategi Segmentasi Pasar}

Pengertian Segmentasi pasar adalah proses membagi pasar ke dalam kelompok pembeli yang berbeda-beda berdasarkan kebutuhan, karakteristik, serta perilaku yang membutuhkan bauran produk dan bauran pemasaran tersendiri. Segmentasi pasar adalah proses menempatkan konsumen dalam kelompok-kelompok di pasar produk, sehingga para calon pembeli memiliki tanggapan serupa dengan strategi pemasaran dalam penentuan posisi perusahaan. (Setiadi. 2003:55).

2. Strategi Penentuan Pasar Sasaran

Strategi penentuan pasar sasaran adalah suatu proses pemilihan besar atau luasnya segmen sesuai dengan kemampuan suatu perusahaan untuk memasuki segmen tersebut. Sebagian besar perusahaan memasuki sebuah pasar baru dengan melayani satu segmen tunggal, dan jika nantinya terbukti berhasil, maka mereka menambah segmen dan kemudian memperluas secara vertikal atau horizontal, sehingga dalam mempelajari pasar sasaran harus mengevaluasi tiga faktor (Umar, 2001:46) yaitu:

a. Ukuran dan pertumbuhan segmen

b. Daya tarik struktural segmen

c. Sasaran dan sumber daya

3. Strategi Penentuan Pasar Sasaran

Penentuan posisi pasar (positioning) adalah suatu strategi untuk mengambil posisi pasar pada benak konsumen, hingga nanti strategi ini menyangkut bagaimana membangun kepercayaan, keyakinan, dan kompetensi pada persepsi pelanggan. Menurut Philip Kotler, positioning adalah kegiatan membuat citra dan memosisikan diri di pikiran konsumen.

\section{Konsep Bauran Pemasaran (Marketing Mix)}

Manajemen pemasaran dikelompokkan dalam empat aspek yang menurut Kotler dan Amstrong (2004:78) disebut dengan bauran pemasaran (marketing mix) yang definisinya adalah suatu kumpulan alat pemasaran taktis terkendali yang digabungkan oleh perusahaan untuk menghasilkan tanggapan yang diinginkannya di suatu pasar sasaran. Bauran pemasaran terdiri dari empat kelompok variabel, yaitu:

1. Produk (Product)

Produk yaitu gabungan dari barang dan jasa yang ditawarkan perusahaan kepada pasar sasaran. Elemen-elemen yang termasuk dalam bauran produk adalah aneka macam produk, kualitas, design, merek, kemasan, serta layanan.

2. Harga (Price)

Harga adalah jumlah uang yang harus dibayarkan pelanggan untuk mendapatkan suatu produk yang dibeli. Harga merupakan satu-satunya unsur bauran pemasaran yang menghasilkan pendapatan, sedangkan unsur-unsur yang lainnya menghasilkan biaya. Harga adalah unsur bauran pemasaran yang paling mudah disesuaikan dan membutuhkan 
waktu yang sangat singkat, sedangkan ciri khas produk, saluran distribusi dan promosi membutuhkan lebih banyak waktu.

\section{Distribusi (Place)}

Distribusi atau saluran pemasaran meliputi suatu kegiatan perusahaan yang membuat produk tersedia bagi pelanggan. Saluran distribusi adalah rangkaian organisasi yang saling bergantung satu dengan yang lain dan juga terlibat dalam proses untuk menjadikan produk atau jasa siap untuk digunakan atau dikonsumsi oleh konsumen. Saluran distribusi dapat didefinisikan sebagai kumpulan perusahaan dan perorangan yang mengambil alih hak atau membantu dalam pengalihan hak atas barang atau jasa tertentu selama barang atau jasa tersebut telah berpindah dari produsen ke konsumen (Kotler, 2005).

4. Promosi (Promotion)

Promosi dapat diartikan sebagai aktivitas yang menyampaikan informasi tentang produk atau jasa dan membujuk pelanggan untuk membeli produk tersebut. Pengertian promosi menurut Kotler (2005) adalah berbagai macam kegiatan yang dilakukan oleh produsen untuk memberitahukan atau menjelaskan manfaat dari produknya, membujuk, dan mengingatkan para konsumen sasaran agar membeli produk tersebut. Secara rinci tujuan promosi menurut Tjiptono (2008: 221-222) adalah sebagai berikut:

a. Menginformasikan produk

b. Membujuk pelanggan sasaran untuk membeli produk

c. Mengingatkan pelanggan akan produk

\section{Manfaat Pemasaran}

Pemasaran tentunya memiliki manfaat sehingga semua hal yang dilakukan merupakan wujud untuk memajukan bisnis, dengan memahami hal tersebut maka pemasaran semakin terarah. Manfaat pemasaran bagi penjual adalah dengan melakukan pemasaran maka penjual menemukan metode efektif untuk mencapai tujuan dengan penggunaan modal yang dapat diminimalisir, serta dapat mengatur momen yang tepat untuk menarik konsumen. Manfaat pemasaran bagi konsumen retail (eceran) adalah mempermudah proses pembelian dan dapat menghemat waktu. Pemasaran dengan menggunakan katalog juga dapat mempermudah konsumen untuk bebas melihat dari memilih produk yang di inginkan. Adapun bagi konsumen grosir adalah manfaat harga yang akan di berikan jelas lebih murah karena pemesanan dalam jumlah besar, selain itu akan ada proses tawar menawar yang tidak dilihat oleh banyak orang.

\section{Tujuan Pemasaran}

Selain manfaat tentunya pemasaran juga memiliki tujuan yang melandasinya yang mana tujuan tersebut agar pemasaran produk yang ditawarkan kepada konsumen dapat dilakukan dengan biaya yang lebih terjangkau. Penawaran lebih terjangkau tersebut dikarenakan pemilik produk menawarkan secara langsung tanpa meminta perantara dari jasa lain. Menurut Kotler dan Keller tujuan melakukan pemasaran adalah untuk mengetahui keinginan masyarakat agar nantinya produk yang kita ciptakan sesuai dengan keinginan dan kebutuhan masyarakat dan memiliki nilai jual tinggi.

\section{Konsep-Konsep Pemasaran}

Menurut Swastha (1979:17) "Konsep pemasaran adalah sebuah falsafah bisnis yang menyatakan bahwa pemuasan kebutuhan konsumen merupakan syarat ekonomi dan sosial bagi kelangsungan hidup perusahaan". Menurut Kotler (1997:17) konsep pemasaran 
adalah menjadi lebih efektif dari pada para pesaing dalam memadukan kegiatan pemasaran untuk menetapkan dan memenuhi kebutuhan dan keinginan pasar sasaran

\section{Pemasaran memiliki konsep mendasar bagaimana cara perusahaan melakukan kegiatan pemasaran, yaitu :}

1) Konsep Berwawasan Produksi

Pada konsep ini dijelaskan bahwa konsumen akan lebih tertarik dengan produk yang mudah didapatkan dan harganya terjangkau sehingga fokus utamanya yaitu dengan meningkatkan efisiensi produksi dengan memperluas proses distribusi

2) Konsep Berwawasan Produk

Pada konsep ini dijelaskan bahwa konsumen akan lebih tertarik dengan produk yang memiliki mutu dan kinerja yang terbaik sehingga fokus utamanya yaitu dengan membuat produk yang memiliki kualitas terbaik dan terus berinovasi agar kualitas menjadi lebih baik lagi

3) Konsep Berwawasan Penjualan

Pada konsep ini dijelaskan bahwa konsumen tidak terlalu tertarik untuk membeli suatu produk dalam jumlah cukup, sehingga perusahaan harus melakukan pemasaran terhadap suatu produk agar konsumen berminat untuk membeli dalam jumlah yang cukup.

4) Konsep Berwawasan Pemasaran

Pada konsep ini dijelaskan bahwa proses mencapai tujuan dengan memenuhi keinginan dan kebutuhan pasar dan efisiensi dari persaingan pasar. Konsep ini di dasarkan pada empat faktor utama yaitu pasar sasaran, kebutuhan pelanggan, pemasaran yang terkoordinasi, serta keuntungan.

5) Konsep Berwawasan Pemasaran bermasyarakat

Pada konsep ini dijelaskan bahwa perusahaan memiliki tugas yaitu memenuhi kebutuhan dan keinginan serta kepentingan pasar dan dapat lebih efektif dan efisien dibandingkan dengan pesaing dengan mempertahankan kesejahteraan konsumen.

\section{Strategi Pemasaran}

Menurut Craven dikutip dari Purwanto (2008:151), Strategi pemasaran yaitu sebagai upaya meningkatkan suatu produk dan pelaksanaan kegiatan dalam strategi penentuan pasar sasaran bagi produk pada tiap unit bisnis, penetapan tujuan pemasaran dan pengembangan, pelaksanaan, serta pengelolaan strategi program pemasaran, penentuan posisi pasar yang dirancang untuk memenuhi keinginan konsumen pasar sasaran. Strategi diperlukan dalam memasarkan produk agar dapat memasarkan produk secara efektif dan efisien sehingga tujuan dari pemasaran tersebut dapat tercapai. Strategi pemasaran yaitu rencana yang dibuat oleh perusahaan dalam memanfaatkan sumber daya yang dimiliki dengan sebaik-baiknya untuk mencapai tujuan perusahaan. Strategi pemasaran terdiri dari dua bagian, yaitu :

1) Seleksi dan analisis pasar sasaran

2) Menciptakan dan menjaga kesesuaian bauran pemasaran, perpaduan antara produk, harga, distribusi dan promosi. (Machfoedz, 2005:73)

Sedangkan menurut Tull dan Kahle (1990) dalam Fandy Tjiptono (1997:6), Strategi pemasaran dapat digunakan sebagai pedoman yang direncanakan untuk mencapai tujuan perusahaan dengan mengembangkan keunggulan dalam bersaing yang berkelanjutan melalui pasar yang dimasuki dan program pemasaran yang digunakan untuk 
melayani pasar sasaran tersebut. Jadi dapat disimpulkan bahwa strategi pemasaran merupakan suatu cara untuk mencapai tujuan perusahaan dengan memaksimalkan sumber daya yang ada, mengembangkan keunggulan bersaing dan program pemasaran yang ada sehingga pasar konsumen dapat dilayani dengan baik serta perusahaan dapat unggul dibandingkan pesaing.

\section{METODE PENELITIAN}

Metodologi penelitian merupakan cara untuk mendapatkan data yang dibutuhkan yang berhubungan dengan masalah dalam penelitian. Pada proses penelitian, metode yang digunakan yaitu survei dan wawancara. Proses dalam pengumpulan data yang akan dilaksanakan oleh peneliti yaitu dengan menentukan subjek penelitian yang akan di wawancarai peneliti untuk mendapatkan data eksternal.

\section{Instrumen Penelitian}

Peneliti pada penelitian ini melakukan pendekatan kualitatif yang mana kami melakukan observasi atau survei langsung pada Rumah Makan Sambel Alu. Peneliti menggunakan pendekatan kualitatif mendapatkan informasi bagaimana proses kepemimpinan pada Rumah Makan Sambel Alu dengan mewawancarai konsumen serta manajer dari Rumah Makan Sambel Alu. Peneliti pada penelitian ini menganalis apa saja faktor-faktor internal dan eksternal di Rumah Makan Sambel Alu untuk mengetahui bagaimana strategi pemasaran yang tepat untuk meningkatkan daya saing pemasaran produk dengan menggunakan analisis SWOT.

Wawancara yang dilakukan pada penelitian ini yaitu dengan cara bertanya langsung kepada konsumen serta kepada manajer dari Rumah Makan Sambel Alu. Matriks IFE merupakan analisis lingkungan internal yang terdiri dari kekuatan dan kelemahan perusahaan, sedangkan matriks EFE merupakan analisis lingkungan eksternal dimana variabel yang digunakan terdiri dari peluang dan ancaman bagi perusahaan. Pada tahap ini, instrumen penelitian adalah wawancara dan survei. Pertanyaan yang diberikan kepada narasumber berisi tentang aspek-aspek internal dan eksternal dari Rumah Makan Sambel Alu.

\section{Penentuan Variabel SWOT}

Analisis SWOT (Strength, Weakness, Opportunity, Threat) adalah suatu proses penelitian dari beberapa faktor untuk merumuskan strategi dari perusahaan. Analisis SWOT yang berasal dari pemikiran akal sehingga dapat memaksimalkan kekuatan (strength) dan peluang (oppurtunities), serta dapat dapat meminimalisir kelemahan yang dimiliki (weakness) dan ancaman (threat) yang ada. Pada saat pengambilan keputusan strategis selalu berhubungan dengan adanya misi, tujuan, strategi dan kebijakan yang dimiliki oleh perusahaan. Jadi, pada proses perencanaan strategi sebelumnya harus mengetahui apa saja faktor-faktor strategis yang dimiliki oleh perusahaan yaitu, kekuatan, kelemahan, peluang dan ancaman. Hal ini dapat disebut dengan analisis SWOT.

Variabel - variabel yang ada dalam analisis SWOT terdiri dari dua bagian, yaitu variabel internal yaitu strengths (kekuatan) dan weaknesses (kelemahan), dan variabel eksternal yaitu opportunities (peluang) dan threats (ancaman). Variabel-variabel diperoleh dari hasil observasi atau wawancara dengan manajer Rumah Makan Sambel Alu dan konsumen: 


\section{A. Lingkungan Internal}

1. Kekuatan

1) Buat sambalnya pedas kemudian bisa makan sambal sepuasnya.

2) Harganya terjangkau.

3) Tempat nyaman dan area parkir luas.

4) Nasinya banyak rasa dan ayam yang memiliki cita rasa yang khas.

5) Pelayanannya cepat,ramah dan rasa makanan tidak berubah

2. Kelemahan

1) Lalapan terlalu sedikit.

2) Kurang nyaman karena sedikit bising.

3) Harganya lumayan mahal

\section{B. Lingkungan Eksternal}

Peluang

1) Adanya go food mempermudah transaksi pembelian.

2) Untuk rasa tidak ada yang menyamakan rasa.

3) Untuk rasa tidak pernah berubah.

C. Ancaman

1) Pesaing sambal alu yaitu Jack Resto.

\section{Uji Kredibilitas dan Dependabilitas}

Data pada penelitian kualitatif dinyatakan valid jika tidak ada perbedaan antara hasil dari peneliti dengan yang sesungguhnya terjadi pada objek yang diteliti. Uji valid atau tidaknya data dalam penelitian kualitatif meliputi:

1) Uji Kredibilitas

Uji kredibilitas data dari hasil penelitian kualitatif dengan melakukan pengamatan yang berkelanjutan, meningkatkan ketekunan dalam proses penelitian, serta diskusi dengan pihak lain yang memiliki keahlian yang terkait dengan topik penelitian. Pada penelitian kualitatif, data dikatakan valid jika tidak ada yang membedakan antara hasil yang dilaporkan oleh penelitian dengan kenyataan yang terjadi

2) Uji Dependabilitas

Uji dependabilitas pada penelitian kuantitatif merupakan kemampuan proses penelitian untuk diulang oleh peneliti lain sedangkan dalam penelitian kualitatif, dependabilitas dilakukan dengan melihat seluruh proses penelitian. Dengan cara, pembimbing melihat keseluruhan aktivitas peneliti dalam melakukan proses penelitian mulai dari menentukan masalahnya.

\section{Analisis Data}

Analisis SWOT adalah analisis yang digunakan untuk meneliti faktor secara teratur dan logis untuk merumuskan strategi perusahaan. Analisis ini didasarkan pada logika yang dapat memaksimalkan kekuatan, dan peluang namun secara bersamaan dapat meminimalkan kelemahan dan ancaman (Rangkuti 2004:18)

\section{Analisis SWOT}

Analisis SWOT bermanfaat untuk mengetahui posisi dari Rumah Makan Sambel Alu berdasarkan kekuatan, kelemahan, peluang dan ancaman yang dimiliki oleh Rumah Makan Sambel Alu 


\section{Cara analisis SWOT}

Dalam penelitian ini Rumah Makan Sambel Alu dapat diketahui kinerja dengan kombinasi faktor internal dan eksternal, yang mana kedua faktor tersebut harus dipertimbangkan dalam melakukan analisis SWOT

\section{HASIL PENELITIAN DAN PEMBAHASAN}

Hasil yang didapat dari analisis Rumah Makan Sambel Alu ini adalah terdapat tabel bobot faktor internal dan eksternal. Tabel 1 menunjukkan matrik internal terdiri dari tabel kekuatan dan kelemahan. Pada matrik kekuatan memiliki jumlah bobot 0,7 sedangkan skor 2,41 untuk matrik kelemahan dengan jumlah bobot 1,00 memiliki skor 3,34. Pada Tabel 2 menunjukkan matrik eksternal terdapat tabel peluang dan ancaman. Pada matrik peluang memiliki jumlah bobot 0,9 dengan skor sebesar 3,02, sedangkan matrik ancaman memiliki jumlah bobot 1,00 dengan skor sejumlah 3,22.

Tabel 1. Matrik Internal Faktor Analisis

\begin{tabular}{|c|l|c|c|c|}
\hline No & \multicolumn{1}{|c|}{ Kekuatan } & Bobot & Peringkat & $\begin{array}{c}\text { Skor } \\
\text { Tertimbang }\end{array}$ \\
\hline 1 & $\begin{array}{l}\text { Sambal nya pedas dan bisa makan } \\
\text { sambal sepuasnya }\end{array}$ & 0,20 & 4 & 0,80 \\
\hline 2 & Harganya terjangkau & 0,08 & 2 & 0,16 \\
\hline 3 & $\begin{array}{l}\text { Tempat nyaman dan area parkir } \\
\text { luas }\end{array}$ & 0,10 & 3 & 0,30 \\
\hline 4 & $\begin{array}{l}\text { Nasinya banyak rasa dan rasa } \\
\text { ayamnya khas }\end{array}$ & 0,13 & 3 & 0,39 \\
\hline 5 & $\begin{array}{l}\text { Pelayanannya cepat, ramah dan } \\
\text { rasa makanan tidak berubah }\end{array}$ & 0,19 & 4 & 0,76 \\
\hline
\end{tabular}

\begin{tabular}{|c|l|c|c|c|}
\hline No & \multicolumn{1}{|c|}{ Kelemahan } & Bobot & Peringkat & $\begin{array}{c}\text { Skor } \\
\text { Tertimbang }\end{array}$ \\
\hline 1 & Lalapan terlalu sedikit & 0,05 & 2 & 0,10 \\
\hline 2 & $\begin{array}{l}\text { Kurang nyaman karena sedikit } \\
\text { bising }\end{array}$ & 0,18 & 4 & 0,72 \\
\hline 3 & Harganya lumayan mahal & 0,7 & 2 & 0,14 \\
\hline \multicolumn{2}{|c|}{ Total } & 1,00 & 24 & 3,34 \\
\hline
\end{tabular}

Sumber : data diolah

Setelah menganalisis kekuatan, kelemahan, peluang dan ancaman yang dimiliki oleh Rumah Makan Sambel Alu, kemudian dapat membuat suatu materi untuk mengetahui dimana posisi perusahaan berada dalam persaingan. Dalam matriks ini dapat di lihat dengan jelas bagaimana peluang dan ancaman yang dihadapi oleh perusahaan. Dalam pembahasan ini, digunakan analisis SWOT yang akan membandingkan antara faktor eksternal (peluang dan ancaman) dengan faktor internal (kekuatan dan kelemahan). Penelitian menunjukkan bahwa kinerja perusahaan dapat ditentukan oleh kombinasi faktor internal san eksternal. 
Tabel 2. Matriks Eksternal Faktor Analisis

\begin{tabular}{|c|l|c|c|c|}
\hline No & \multicolumn{1}{|c|}{ Peluang } & Bobot & Peringkat & $\begin{array}{c}\text { Skor } \\
\text { Tertimbang }\end{array}$ \\
\hline 1 & $\begin{array}{l}\text { Adanya Go - food mempermudah } \\
\text { transaksi pembelian }\end{array}$ & 0,32 & 4 & 1,28 \\
\hline 2 & $\begin{array}{l}\text { Untuk rasa tidak ada yang } \\
\text { menyamakan }\end{array}$ & 0,28 & 3 & 0,84 \\
\hline 3 & Untuk rasa tidak pernah berubah & 0,30 & 3 & 0,90 \\
\hline No Ancaman & Bobot & Peringkat & $\begin{array}{c}\text { Skor } \\
\text { Tertimbang }\end{array}$ \\
\hline 1 & $\begin{array}{l}\text { Pesaing Sambal Alu yaitu Jack } \\
\text { Resto }\end{array}$ & 0,10 & 2 & 0,20 \\
\hline \multicolumn{2}{|c|}{ Total } & 1,00 & 12 & 3,22 \\
\hline
\end{tabular}

Sumber : data diolah

\section{Analisis Matriks SWOT}

Berdasarkan analisis matriks SWOT dapat disimpulkan bahwa faktor internal dari Sambel Alu kuat, karena skor total tertimbang sebesar 2,91. Dan peluang Sambel Alu pun lebih besar dibandingkan dengan faktor ancaman, sehingga Sambel Alu seharusnya sudah mampu bersaing dengan rumah makan lainnya yang memiliki cita rasa yang baik dan popularitas yang sangat baik juga.

Pengembangan Strategi Pemasaran Dari Analisis SWOT Sambel Alu, yaitu:

1) Strategi SO (Strenghts Opportunities)

Sambel Alu harus mempertahankan cita rasa khas yang dimiliki seperti sambal, nasi dan ayam yang menjadikan kekuatan untuk menjadi tempat kuliner terbaik di Bandar Lampung serta memiliki harga yang lumayan terjangkau membuat siapa saja bisa mencicipi menu - menu yang disajikan oleh Sambel Alu. Semakin dikenalnya Sambel Alu ini dan diterima oleh masyarakat akan membuat Sambel Alu untuk membuka beberapa cabang yang tersebar di beberapa tempat, karena pengunjung yang datang bukan hanya dari daerah Bandar Lampung saja yang membuat pemilik Sambel Alu untuk membuka cabang tersebut.

2) Strategi WO (Weakness Opportunies)

Strategi yang dapat dilakukan adalah:

a) Selalu menghargai pendapat para konsumen tentang Sambel Alu. Kita ingin selalu memberikan yang terbaik untuk para pelanggan dan kita selalu beranggapan kalau bisnis kita sudah disukai oleh banyak orang, hanya saja terkadang masih ada saja orang - orang yang tidak suka dengan pelayanan yang kita berikan maka dari itu kita harus selalu mendengarkan saran dari konsumen dan tidak hanya mendengarkan tetapi diaplikasikan pula.

b) Memberikan kenyamanan terhadap pelanggan, keinginan para konsumen bukan hanya rasa yang enak tetapi kenyamanan pun menjadi hal terpenting bagi mereka. Perlu diketahui oleh Sambel Alu kenyamanan membuat orang - orang yang datang akan menjadi senang dan akan datang lagi jika Sambel Alu tidak memikirkan kenyamanan sulit untuk pemilik mempertahankan konsumen - konsumen yang lain. 


\section{3) Strategi ST (Strenghts Treaths)}

a) Dengan mengetahui siapa pesaing dari Sambel Alu jika ada pesaing lain Sambel Alu harus mempertahankan eksistensi yang dimiliki.

b) Melakukan kerjasama yang baik antara manajer dan karyawan, untuk memuaskan konsumen

c) Mendirikan beberapa cabang menjadi satu alasan persaingan tarif.

4) Strategi WT (Weakness Treaths)

a) Memberikan potongan harga setiap hari Jum'at atau dengan cara lainnya

b) Selalu menjaga hubungan yang baik dengan pelanggan

c) Memberikan sikap yang baik dan ramah terhadap pelanggan

d) Mengerti apa yang diinginkan pelanggan, dan harus menentukan strategi pemasaran dengan sebaik mungkin untuk menghindari ancaman dan meminimalkan kelemahan.

\section{Faktor Lingkungan Eksternal}

Lingkungan eksternal adalah suatu proses yang digunakan untuk merencanakan strategi agar bisa memantau dan menentukan peluang dan ancaman terhadap perusahaan. Kekuatan eksternal dapat dibagi menjadi lima kategori besar yaitu kekuatan ekonomi, sosial, budaya, demografi dan lingkungan.

Lingkungan eksternal memiliki kekuatan yang sangat berpengaruh pada perusahaan dan memiliki kekuatan pada setiap kategorinya. Begitu pula pada Rumah Makan Sambel Alu yang memiliki kekuatan yang bagus disetiap kategorinya pintar dalam mengambil peluang dan dapat bersaing sampai saat ini.

Faktor eksternal yang terdapat pada Sambel Alu berdasarkan analisis dan hasil penelitian kami, sebagai berikut ini:

a. Faktor Ekonomi

Sering tidak stabilnya harga - harga bahan makanan membuat rumah makan ini harus selalu siap menghadapi apa saja yang terjadi di pasaran seperti kenaikan harga sampai kurangnya persediaan bahan - bahan makanan di pasaran. Harga yang terkadang melonjak naik dan tidak memungkinkan untuk Sambel Alu menaikkan harga pada menu rumah makan membuat Sambel Alu harus memikirkan jalan keluarnya agar harga tetap sama tetapi rumah makan tidak mengalami kerugian.

b. Faktor Sosial Budaya

Pada Sambel Alu selalu menerapkan ikatan keorganisasian yang kuat, mereka memiliki cara unik untuk menyapa para pelanggannya langsung, dan rumah makan ini juga menerapkan keagamaan yang sangat tinggi seperti menutup rumah makan setiap azan zuhur, dan melakukan sedekah di setiap hari Jum'at.

c. Faktor Politik, Pemerintahan, dan Hukum

Di setiap cabang rumah makan Sambel Alu sudah memiliki sertifikat halal, dan memiliki surat izin beroperasi dari pemerintah. Untuk keamanan hukum sudah terjamin semuanya.

d. Faktor Teknologi

Faktor teknologi yang semakin canggih membuat Sambel Alu berinovasi untuk mengambil keuntungan yang lebih dengan menggunakan teknologi. Dengan cara menggunakan aplikasi ojek online seperti go - food dan grab food. Mulai dari aplikasi itu Sambel Alu bisa menambah orderan di setiap harinya dan mempermudah konsumen untuk memesan makanan yang di inginkan dari Sambel Alu. 


\section{Faktor Lingkungan Internal}

Lingkungan internal adalah proses dimana perencanaan strategi mengkaji pemasaran dan distribusi sebuah perusahaan, produksi dan operasi mulai dari sumber daya, karyawan, yang berhubungan dengan keuangan dan bisa mengetahui kelemahan dan kekuatan yang dimiliki oleh suatu perusahaan.

Karyawan Rumah Makan Sambel Alu harus bersikap ramah saat melayani konsumen. Sambel Alu juga memiliki manajer yang tegas untuk mengatur karyawan - karyawan yang lainnya agar dapat mengerjakan tugas sesuai aturan yang ada dengan baik dan benar. Dan untuk bagian keuangan juga misalnya kasir memiliki 2 orang karyawan yang berjaga di kasir agar penghitungan ulang pada proses pembayaran dapat berjalan lebih baik.

Faktor - faktor internal yang terdapat pada Rumah Makan Sambel Alu yaitu:

a. Manajemen

Manajemen yang dilakukan oleh Sambel Alu sangatlah baik, hanya saja tidak semuanya dapat diberi tahu oleh pihak rumah makan. Untuk proses produksi Sambel Alu memproduksi makanannya dengan sangat baik dari bahan - bahannya sampai ketersediaan menu makanan jadi semua pelanggan yang datang tidak akan kehabisan makanan.

b. Pemasaran

Rumah Makan Sambel Alu sendiri memasarkan menu makanan bukan hanya offline saja tetapi melalui media sosial atau secara online, memilik beberapa cabang wilayah yang strategis. Barang yang dijual pun bukan hanya menu nasi dan lauk saja tetapi Sambel Alu juga menjual sambel kemasan yang menjadi ikon terfavorit pada Sambel Alu. 


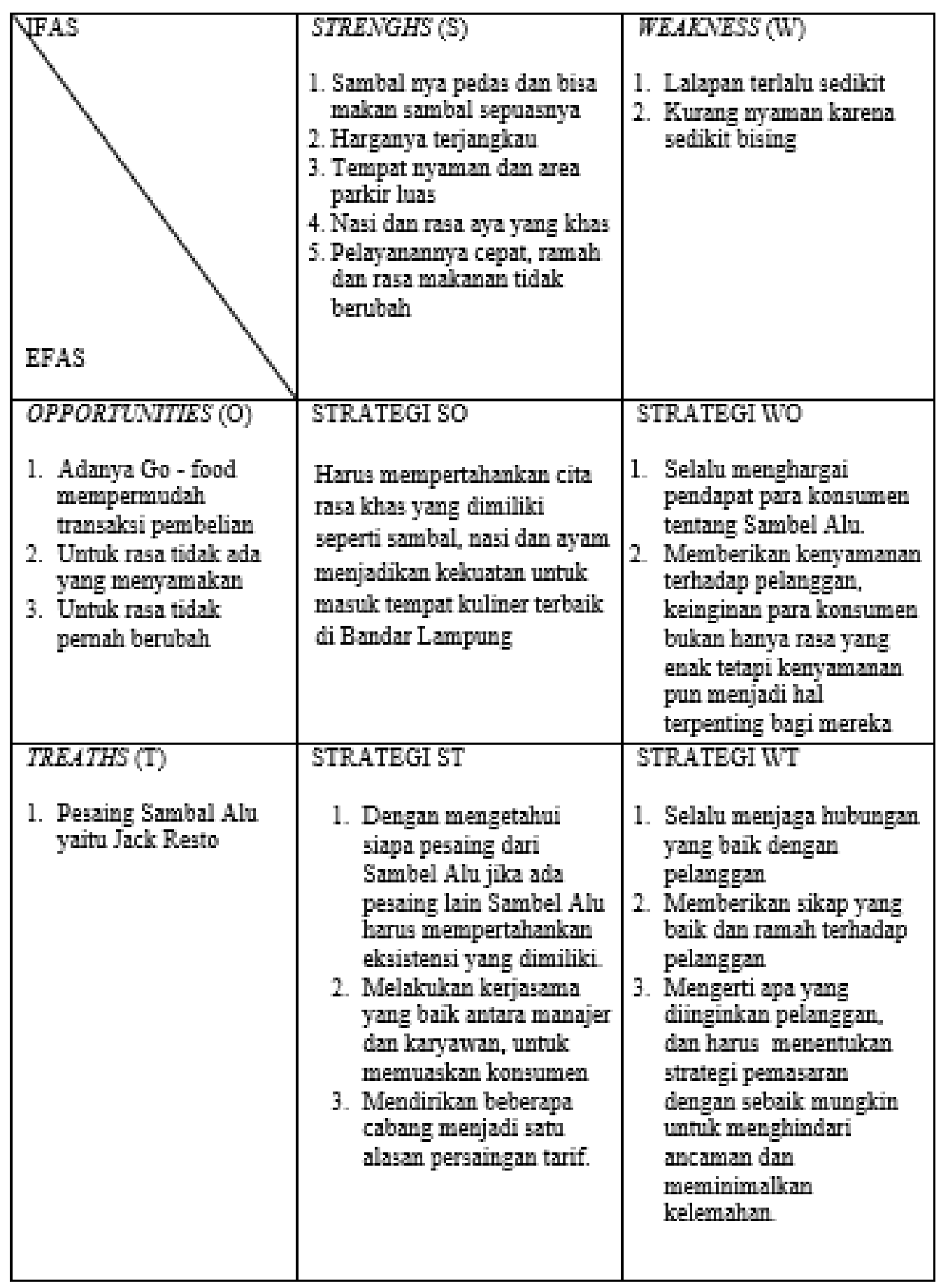

Gambar 1. Analisis SWOT Sambal Alu 


\section{KESIMPULAN}

Agar dapat bertahan kemudian berkembang sebuah bisnis maka memerlukan strategi SWOT yang ada melalui kekuatan, kelemahan, ancaman, dan peluang yang dapat disimpulkan sebagai berikut. Semakin dikenalnya Sambel Alu ini dan diterima oleh masyarakat banyak membuat Sambel Alu membuka beberapa cabang yang tersebar di beberapa tempat, karena pengunjung yang datang bukan hanya dari daerah Bandar Lampung. Mempertahankan pesaing yang baik dan selalu memberikan yang terbaik untuk para pelanggan yang selalu beranggapan kalau bisnis sudah disukai oleh banyak orang. Memberikan kenyamanan terhadap pelanggan, keinginan para konsumen bukan hanya rasa yang enak tetapi kenyamanan pun menjadi hal terpenting. Untuk menjadi kekuatan di Rumah Makan Sambel Alu ini maka mempertahankan cita rasa khas yang di miliki. Strategi yang digunakan membuat pemasaran yang nantinya menarik perhatian dari konsumen, seperti memberikan promosi. Kemudian Rumah Makan Sambel Alu harus menentukan strategi pemasaran sebaik mungkin untuk menghindari ancaman dan meminimalkan kelemahan.

\section{SARAN}

Berdasarkan penelitian yang telah dilakukan, hasil dan pembahasan yang telah disampaikan, serta simpulan yang telah disampaikan diatas, maka saran yang diberikan oleh peneliti adalah sebagai berikut. Melakukan inovasi pemasaran agar promosi yang di berikan dapat efektif. Pesatnya perkembangan usaha rumah makan menjadikan persaingan antar rumah makan pun lebih ketat. Hal ini membuat "Rumah Makan Sambel Alu" juga harus berpikir keras untuk memberikan perhatian khusus serta meningkatkan kualitas dari Rumah Makan Sambel Alu. Dalam peningkatan kualitas rumah makan Sambel Alu pemilik diharapkan tepat dan efisien dalam mengelola biaya kualitas yang harus dikeluarkan.

Faktor kualitas pelayanan juga memengaruhi, yang mana menyangkut pelayanan pada konsumen. Kualitas pelayanan merupakan suatu hal yang penting diperhatikan agar dapat unggul dalam persaingan usaha rumah makan. Apabila kualitas pelayanan yang diberikan sesuai dengan harapan konsumen, maka akan diperoleh kepuasan konsumen yang maksimal. Konsumen yang puas dapat menciptakan kesetiaan konsumen kepada Rumah Makan Sambel Alu yang memberikan kualitas pelayanan yang memuaskan. Pengelola rumah makan ini sebaiknya lebih memerhatikan lagi kualitas dalam melayani konsumen serta mengolah bahan baku menjadi lebih baik lagi.

\section{DAFTAR RUJUKAN}

Ahmad, F. M. (2008). Analisis Strategi Untuk Meningkatkan Penjualan Kendaraan Motor Pada Cv Turangga Mas Motor : Journal of Economic, 4.

Cahyono, P. (2016). Implementasi Strategi Pemasaran Dengan Menggunakan Metode SWOT Dalam Upaya Meningkatkan Penjualan Produk Jasa Asuransi Kecelakaan dan Kematian Pada PT. Prudential Cabang Lamongan : Jurnal Penelitian Ilmu Manajemen, 1, 129.

David, F. R. 2012. Strategic Management (Manajemen Strategis Konsep). Salemba Empat. Jakarta.

Elyarni, R \& Hermanto. (2016). Analisis SWOT Terhadap Pemasaran SAP Express Pada PT. SAP : Jurnal Metris, $17,81-88$.

Hasan. 2013. Riset Pemasaran Dan Penilaian Konsumen. Jakarta: PT Gramedia Pustaka. 
Hendika, D.W \& Arifin, Z. (2015). Analisis Strategi Pemasaran Untuk Meningkatkan Daya Saing UMKM (Studi Pada Batik Diajeng Solo) : Jurnal Administrasi Bisnis, $29,60-62$.

Jauch, L. R dan G. William. 2003. Manajemen Strategis dan Kebijakan Perusahaa. Erlangga. Jakarta.

Kotler, P. 2003. Imarketing Management, Eleventh Ed. Pearson Educated inc, New Jersey.

Kotler, P. Armstrong, Gary. 2008. Prinsip-Prinsip Pemasaran. (Alih bahasa Bob Sabran). Jilid 1. Edisi kedua belas. Jakarta: Erlangga.

Kotler, P. Armstrong, Gary. 2009. Principles of Marketing. 12th Edition. New Jersey. Perntice Hall, Pearson Education, Inc,.

Kotler, P. 1997. Manajemen Pemasaran. Jakarta: Macanan Jaya, Indonesia.

Luh, N. P. S. (2016). Analisis SWOT Sebagai Dasar Menentukan Strategi Pemasaran Kompetitif (Studi Kasus : Usaha Jasa Dekorasi X) : SENTIKA, 10. https://fti.uajy.ac.id/sentika/publikasi/makalah/2016/12.pdf

Noor, S. (2014). Penerapan Analisis SWOT Dalam Menentukan Strategi Pemasaran Daihatsu Luxio Di Malang (Studi Kasus Pada PT. Astra International Tgk. Daihatsu Malang) : Jurnal INTEKNA, 2, 3.

Nugrohojati, A. S. 2013. Perencanaan Strategi Pemasaran Melalui Metode SWOT Guna Meningkatkan Volume Penjualan (Studi Kasus: PT.CI Kemang No. 112 Jakarta Selatan). Skripsi Teknik Industri. Fakultas Teknik Matematika dan Ilmu Pengetahuan Alam, Universitas Indraprasta PGRI. http://eprints.itn.ac.id/4121/9/SKRIPSI\%20FULL.pdf

Swastha. 1979. Manajemen Bisnis. Jakarta: Rineka Cipta.

Sulistiani, D. (2014). Analisis SWOT Sebagai Strategi Perusahaan Dalam Memenagngkan Persaingan Bisnis : El - Qudwah, 1 - 3.

Tamara, Angelica. (2016). Impelemtasi Analisis SWOT Dalam Strategi Pemasaran Produk Mandiri Tabungan Bisnis: Jurnal Riset Bisnis dan Manajemen, 4, 395 - 406.

Tririno, W. R. 2010. Manajemen Strategi Analisis SWOT Dan Porter. Skripsi Fakultas Teknik, Universitas Indonesia.

Yadi, Hendri. (2014). Penerapan Analisis SWOT Manajemen Pemasaran Bisnis Developer: Jom FISIP, 1, 3. 